\title{
Kestabilan Model Epidemi Dengan Laju Insidensi Jenuh
}

\section{Stability of a Epidemic Model with Saturated Incidence}

\author{
Roni Tri Putra ${ }^{1)} \&$ Quinoza Guvil ${ }^{2)}$ \\ ${ }^{1)}$ Jurusan Teknik Sipil, Politeknik Negeri Padang, Kampus Unand Limau Manis Padang, Telp. \\ 0751-72590 Fax. 0751-72576. Email : putra_tryronny@yahoo.co.id \\ ${ }^{2)}$ Jurusan Teknik Geodesi, Institut Teknologi Padang, Telp 0751-7055202. \\ Email : quinozaguvil@gmail.com
}

\begin{abstract}
In this paper, it will be studied stability for a SEIR epidemic model with infectious force in latent, infected and immune period with saturated incidence. From the model it will be found investigated the existence and uniqueness solution of points its equilibrium. Existence solution of points equilibrium proved by show its differential equations system of equilibrium continue, and uniqueness solution of points equilibrium proved by show its differential equation system of equilibrium differentiable continue.
\end{abstract}

Keywords : stability, equilibrium points, saturated incidence

\section{PENDAHULUAN}

Penerapan model matematika dan teknik matematika untuk mendalami masalah biosciences dipelajari dalam mathematical biosciences. Salah satu cabang mathematical biosciences adalah mathematical epidemiology, yang mempelajari tentang penyebaran dan pengendalian penyakit. Mempelajari model epidemi yang didalamnya termasuk penyakit penyebab kematian pada suatu populasi total yang berubah merupakan hal penting dalam mathematical epidemiology.

Epidemik merupakan suatu keadaan dimana berjangkitnya suatu penyakit menular dalam populasi pada suatu tempat yang melebihi perkiraan kejadian normal dalam periode yang singkat. Bila penyakit tersebut selalu terdapat dalam suatu tempat begitupun dengan factor penyebabnya maka dikatakan Endemic, kemudian bila penyakit tersebut mempunyai ruang lingkup penyebaran yang sangat luas (global) maka disebut Pandemic. Model epidemik adalah model matematika yang digunakan untuk mengetahui penyebaran penyakit menular, khususnya menyangkut terjadi atau tidaknya keadaan epidemik serta pengaruh yang ditimbulkan.
Perilaku dinamik dari sistem untuk menganalisis dinamika penyebaran penyakit terdapat beberapa model matematika yang sering digunakan. Modelmodel tersebut memiliki konsep yang sama yaitu compartmental epidemiologi (pembagian kelas) yang menggambarkan penyebaran penyakit dari masing-masing kelas. Jadi dalam suatu populasi akan terbagi menjadi beberapa kelas dimana masing-masing kelas mewakili tahapan yang berbeda. Kelas $S$ (susceptible) digunakan untuk mewakili individuindividu yang rentan terhadap infeksi virus, kemudian kelas I (infectious) digunakan untuk mewakili individu-individu yang telah terinfeksi dan mampu menularkan atau menyebarkan penyakit ke individu pada populasi rentan, untuk kelas $R$ (recovered) digunakan untuk mewakili individu-individu terinfeksi yang telah sembuh dari penyakit dan memiliki kekebalan permanen yang artinya individu tersebut tidak akan terinfeksi lagi untuk jenis penyakit yang sama. Namun pada model SIRS, kelas $R$ (recovered) mewakili individu-individu yang telah sembuh dan akan terbebas dari infeksi virus kemudian akan memasuki populasi rentan 
(susceptible) kembali. Pada model-model epidemik yang memperhatikan adanya periode laten(masa inkubasi) seperti model SEIR, MSEIR terdapat kelas E(exposed) yang digunakan untuk mewakili individuindividu yang baru terinfeksi dan memasuki periode latent, dalam periode ini individu tersebut tidak memiliki kemampuan untuk menularkan penyakit ke individu lain sedangkan kelas $M$ (Maternallyderivedimmunity) digunakan untuk mewakili individu-individu yang baru lahir dan memiliki kekebalan pasif yang didapatkan dari ibunya, namun hal ini hanya berlangsung sementara kemudian individu pada kelas $\mathrm{M}$ ini akan memasuki kelas rentan (susceptible).

Berbagai macam penyakit epidemi seperti campak (measles), tubercoloses, malaria dan Human Immunodeficiency Virus(HIV) mempunyai periode laten. Periode laten adalah selang waktu dimana suatu individu terinfeksi sampai munculnya penyakit. Adanya periode laten ini menjadi alasan pembentukan model epidemi SEIR, yakni munculnya kelas exposed. Dalam tulisan ini hanya akan dibahas model epidemi SEIR.

Dengan berbagai asumsi, dikenal berbagai model epidemi, diantaranya SIR, SIRS, SEIR, SEIRS dan SEIS. Dalam model SIR, individu yang sembuh mempunyai kekebalan sehingga tidak lagi menjadi rentan, sedangkan untuk model SIRS individu yang sudah sembuh tidak memiliki kekebalan terhadap penyakit tersebut sehingga dapat menjadi rentan lagi. Dalam model SEIR, SEIRS dan SEIS individu yang rentan melalui masa laten setelah terinfeksi sebelum menjadi terjangkit.

Ada tiga jenis fungsi incidence yang berbeda dalam model epidemi SEIR, yaitu:

a. Mass action incidence, yaitu laju kontak tergantung pada jumlah total populasi. Suatu anggota populasi membuat kontak yang cukup untuk menularkan infeksi dengan rata-rata $\beta N$ anggota populasi lain per unit waktu, dengan $N$ adalah ukuran total populasi dan $\beta$ adalah laju kontak. Karena probabilitas kontak acak oleh satu individu infective dengan satu individu susceptible adalah $\frac{S}{N}$, sehingga jumlah infeksi baru dalam unit waktu per infective adalah $(\beta N)\left(\frac{S}{N}\right)$, yang memberikan ratarata infeksi baru $(\beta N)\left(\frac{S}{N}\right) I=\beta S I$.

b. Standard incidence, yaitu situasi dimana jumlah kontak per infective dalam unit waktu adalah konstan. Laju kontak adalah $\beta$ dan incidence yang berhubungan adalah $\beta \frac{S}{N} I$. Ketika jumlah total populasi $N$ cukup besar, sejak itu jumlah kontak yang dibuat satu individu infective per unit waktu akan terbatas, atau menurun dengan cepat seiring meningkatnya $N$.

c. Saturated incidence. Untuk jumlah individu infective yang cukup besar, jumlah kontak satu individu susceptible per unit waktu tidak selamanya meningkat bergantung linear dengan individu infective. Laju kontak tidak selalu linear, berarti laju tersebut dapat dalam bentuk nonlinear. Hal ini sesuai dengan kenyataan bahwa, seiring meningkatnya jumlah individu infective, maka individu susceptible cenderung mengurangi kontak dengan individu infective. Hal ini menunjukkan adanya saturation effect dalam laju kontak seiring meningkatnya jumlah individu infective.

Dari berbagai literatur belum banyak yang mengkaji model matematika epidemi SEIR dengan laju insidensi jenuh secara sistematis. Sejalan dengan masalah yang 
akan dibahas, penelitian ini mempunyai tujuan sebagai berikut :

1. Membentuk model matematika epidemi SEIR pada populasi manusia dengan laju insidensi jenuh.

2. Menentukan titik-titik ekuilibrium model epidemi SEIR tersebut

3. Menyelidiki eksistensi dan ketunggalan solusi titik ekuilibrium model epidemi SEIR.

Hasil penelitian ini diharapkan dapat :

1. Secara umum diharapkan dapat memberikan manfaat dan sumbangan terhadap ilmu pengetahuan, serta untuk menambah wawasan khususnya dalam bidang matematika terapan.

2. Secara khusus diharapkan dapat memberikan gambaran tentang eksistensi dan ketunggalan solusi titik ekuilibrium model epidemi SEIR dengan kemampuan infeksi pada kelas laten, infeksi dan sembuh dengan laju kontak jenuh.

Metode penelitian dalam tulisan ini adalah dengan cara studi literatur serta bahan pustaka sebagai referensi untuk mempelajari model epidemi SEIR dengan laju insidensi jenuh. Langkah pertama adalah dengan menentukan asumsi-asumsi yang berkaitan dengan model epidemi SEIR sesuai dengan karakteristik penyakit yang dimodelkan, kemudian akan dibuat model matematika epidemi SEIR dalam bentuk sistem persamaan diferensial.

Selanjutnya, menentukan titik-titik ekuilibrium model epidemi SEIR tersebut dengan menggunakan definisi titik ekuilibrium suatu sistem persamaan diferensial. Setelah menentukan titik-titik ekuilibrium model tersebut, langkah selanjutnya menyelidiki eksistensi dan ketunggalan solusi dari titik ekuilibrium model epidemi SEIR tersebut.

Eksistensi solusi dari titik ekuilibrium model epidemi SEIR dibuktikan dengan menunjukkan bahwa sistem persamaan diferensial dari titik ekuilibrium model epidemi SEIR tersebut kontinu, sedangan ketunggalan solusi dari titik ekuilibrium model epidemi SEIR dibuktikan dengan menunjukkan bahwa sistem persamaan diferensial dari titik ekuilibrium model epidemi SEIR tersebut diferensiabel kontinu.

\section{HASIL DAN PEMBAHASAN}

Model SEIR (Susceptible, Exposed, infectious, recovered) pertama kali dikembangkan oleh Kermack dan Mckendrick (1927) dengan memakai asumsi sederhana tentang laju penyebaran dan penyembuhan penyakit. Dalam modelnya, Kermack dan Mckendrick membagi populasi total $(N)$ menjadi empat kelas, yaitu Susceptible $(S(t))$ merupakan jumlah individu yang rentan terinfeksi dan mudah ditulari penyakit, Exposed $(E(t))$ merupakan jumlah individu yang sudah terinfeksi tetapi belum menginfeksi, Infectious $(I(t))$ adalah jumlah individu yang terinfeksi, dan Recovered $(R(t))$ menotasikan jumlah individu yang telah sembuh dari penyakit.

Diberikan rata-rata saturated incidence $g(I) S$ dengan $g(I)$ cenderung menuju suatu titik jenuh (saturation level)ketika I cukup besar. Diasumsikan

$g(I)=\frac{\beta I}{1+\alpha I^{2}}$

Dengan $\beta I$ menunjukkan ukuran kekuatan infeksi dari penyakit dan $1 /\left(1+\alpha I^{2}\right)$ merupakan ukuran ketahanan infeksi (inhibition effect) yang berasal dari perubahan perilaku individu susceptible ketika jumlah individu infective mengalamai peningkatan.

Dalam makalah ini $g(I)$ adalah fungsi nonmonoton sebagai interpretasi dari pengaruh psikologi terhadap peningkatan infective dalam populasi. Untuk individu infective dalam jumlah sangat besar, kekuatan infeksi mengalami penurunan seiring meningkatnya jumlah individu infective. Hal ini sesuai dengan kenyataan bahwa dengan adanya individu infective dalam jumlah besar, menyebabkan populasi 
cenderung melakukan penurunan jumlah kontak per unit waktu, misalnya dengan adanya karantina individu infective atau sikap proteksi individu susceptible. Beberapa contoh pengaruh psikologi di masyarakan secara umum adalah menghindari jabat tangan dalam kasus kolera, serta pemakaian masker wajah, karantina, dan isolasi dalam kasus SARS.

Sebelumnya diasumsikan ketika terjadi kontak dengan individu infectious, individu susceptible menjadi infected pada rata-rata saturated incidence $\frac{\beta S I}{1+\alpha I^{2}}$, dengan $\alpha$ dan $\beta$ bernilai positif. Berdasarkan asumsi tersebut, model SEIR dengan insidensi jenuh adalah:

$$
\begin{aligned}
& \frac{d S}{d t}=b-\frac{\beta S I}{1+\alpha I^{2}}-\mu S ; t \geq 0, \\
& \frac{d E}{d t}=\frac{\beta S I}{1+\alpha I^{2}}-(\mu+e) E ; t>0 \\
& (2) \frac{d I}{d t}=e E-(\gamma+\mu) I ; t \geq 0, \\
& \frac{d R}{d t}=\gamma I-\mu R ; t \geq 0, \\
& S(0)=S_{0}, E(0)=E_{0}, I(0)=I_{0},
\end{aligned}
$$

dengan $b$ adalah laju rekrutmen populasi, $\mu$ adalah laju kematian alami populasi, $\beta$ adalah laju kontak, $\gamma$ adalah laju kesembuhan individu infective, dan $\alpha$ adalah parameter yang menunjukkan ukuran pengaruh psikologi atau pertahanan. Diasumsikan nilai parameter bernilai positif, $b, \beta, \alpha, \mu, e, \gamma>0$, dan nilai awal bernilai nonnegatif, $S_{0}, E_{0}, I_{0}, R(0) \geq 0$. Karena variabel $R$ tidak mempengaruhi tiga persamaan pertama Sistem (2.32), sehingga Sistem tersebut dapat direduksi menjadi Sistem yang lebih sederhana.

$$
\begin{aligned}
& \frac{d S}{d t}=b-\frac{\beta S I}{1+\alpha I^{2}}-\mu S ; t \geq 0, \\
& \frac{d E}{d t}=\frac{\beta S I}{1+\alpha I^{2}}-(\mu+e) E ; t>0 ; \\
& \text { (3) } \frac{d I}{d t}=e E-(\gamma+\mu) I ; t \geq 0,
\end{aligned}
$$

\section{Kepositifan Solusi}

Untuk mempelajari dinamika Sistem (2), pertama diberikan lemma berikut ini.

Lemma 1. Bidang $S+E+I+R=\frac{b}{\mu}$ merupakan invariant manifold dari Sistem (2).

\section{Bukti}

Pertama,dari

$N(t)=S(t)+E(t)+I(t)+R(t) \quad$ pada Sistem (2) diperoleh

$$
\begin{aligned}
& \frac{d}{d t}(S+E+I+R) \\
& =b-\frac{\beta S I}{1+\alpha I^{2}}-\mu S+\frac{\beta S I}{1+\alpha I^{2}}-(\mu+e) E+e E-(\gamma+\mu) I+e E-(\gamma+\mu) I \\
& =b-\mu(S+E+I+R) \\
& =b-\mu N .
\end{aligned}
$$

Oleh karena itu,

$\frac{d N}{d t}=b-\mu N$.

$N(t)=\frac{b}{\mu}$ adalah solusi (4) dan untuk $N\left(t_{0}\right) \geq 0$, solusi umum dari (4) adalah :

$$
\begin{aligned}
& \int_{N\left(t_{0}\right)}^{N} \frac{d N}{b-\mu N}=\int_{t_{0}}^{t} d t \\
& \Leftrightarrow-\left.\frac{1}{\mu} \ln (b-\mu N)\right|_{N\left(t_{0}\right)} ^{N}=t-t_{0} \\
& \Leftrightarrow N=\frac{b}{\mu}-\frac{\left(b-\mu N\left(t_{0}\right)\right) e^{-\mu\left(t-t_{0}\right)}}{\mu} .
\end{aligned}
$$

Sehingga,

$$
\lim _{t \rightarrow \infty} N(t)=\frac{b}{\mu}
$$

Oleh karena itu, himpunan limit Sistem (2) berada pada bidang $S+E+I+R \leq \frac{b}{\mu}$.

Dengan demikian, himpunan

$$
D=\left\{(S, E, I, R) \in R_{+}^{4}: S+E+I+R \leq \frac{b}{\mu}\right\}
$$

adalah invarian positif model (2).

\section{Titik Ekuilibrium}

Pada bagian ini akan dicari titik ekuilibrium Sistem (3). Sistem tersebut mencapai ekuilibrium jika memenuhi

$$
\frac{d S}{d t}=b-\frac{\beta S I}{1+\alpha I^{2}}-\mu S=0 \text {, }
$$


$\frac{d E}{d t}=\frac{\beta S I}{1+\alpha I^{2}}-(\mu+e) E=0$

$\frac{d I}{d t}=e E-(\gamma+\mu) I=0$.

Dari persamaan ketiga Sistem (6) diperoleh $E=\frac{(\gamma+\mu)}{e} I$

Jika nilai $E$ disubstitusikan pada persamaan kedua diperoleh

$$
\begin{aligned}
& \frac{\beta S I}{1+\alpha I^{2}}-\frac{(\mu+e)(\gamma+\mu)}{e} I=0 \\
& \Leftrightarrow\left(\frac{\beta S}{1+\alpha I^{2}}-\frac{(\mu+e)(\gamma+\mu)}{e}\right) I=0
\end{aligned}
$$

(8)

Persamaan (2.38) dipenuhi untuk $S=\frac{(\mu+e)(\mu+\gamma)}{\beta e}\left(1+\alpha I^{2}\right)$ atau $I=0$.

Untuk $I=0$, jika nilai $I$ tersebut disubstitusikan pada persamaan pertama dan ketiga Sistem (6) diperoleh :

$$
S=\frac{b}{\mu}>0 \text { dan } E=0 \text {. }
$$

Jadi, titik ekuilibrium bebas penyakit

Sistem (3) adalah :

$$
\bar{T}=(\bar{S}, \bar{E}, \bar{I})=\left(\frac{b}{\mu}, 0,0\right) .
$$

Untuk $S=\frac{(\mu+e)(\mu+\gamma)}{\beta e}\left(1+\alpha I^{2}\right)>0$, dari persamaan pertama diperoleh :

$$
\begin{gathered}
b-\frac{\beta I}{1+\alpha I^{2}}\left(\frac{(\mu+e)(\mu+\gamma)}{\beta e}\left(1+\alpha I^{2}\right)\right)-\mu\left(\frac{(\mu+e)(\mu+\gamma)}{\beta e}\left(1+\alpha I^{2}\right)\right)=0 \\
\Leftrightarrow \\
\frac{\mu(\mu+e)(\mu+\gamma)}{\beta e}\left(1+\alpha I^{2}\right)+\frac{\beta(\mu+e)(\mu+\gamma)}{\beta e} I-b=0 \\
\Leftrightarrow \quad \Leftrightarrow \quad(\mu+\gamma) \\
\frac{\alpha \mu(\mu+e)(\mu+\gamma)}{\beta e} I^{2}+\frac{\beta(\mu+e)}{\beta e} I+\frac{\mu(\mu+e)(\mu+\gamma)}{\beta e}-b=0
\end{gathered}
$$

Persamaan (10) dapat ditulis dalam bentuk: $c_{2} I^{2}+c_{1} I+c_{0}=0$

dengan

$$
c_{2}=\frac{\alpha \mu(\mu+e)(\mu+\gamma)}{\beta e} \text {, }
$$

$$
\begin{aligned}
& c_{1}=\frac{\beta(\mu+e)(\mu+\gamma)}{\beta e}, \\
& c_{0}=\frac{\mu(\mu+e)(\mu+\gamma)}{\beta e}-b \\
& =b\left(\frac{\mu(\mu+e)(\mu+\gamma)}{\beta e b}-1\right) \\
& =b \frac{\mu(\mu+e)(\mu+\gamma)}{\beta e b}\left(1-\frac{\beta e b}{\mu(\mu+e)(\mu+\gamma)}\right)
\end{aligned}
$$

Nilai $\quad c_{1}, c_{2}>0 \quad$ dan $c_{0}>0 \Leftrightarrow \frac{\beta e b}{\mu(\mu+e)(\mu+\gamma)}<1$ Dengan demikian, solusi dari (10) adalah :

$$
\begin{aligned}
& I_{1}=\frac{1}{2 c_{2}}\left(-c_{1}+\sqrt{c_{1}^{2}-4 c_{2} c_{0}}\right) \\
& I_{2}=\frac{1}{2 c_{2}}\left(-c_{1}-\sqrt{c_{1}^{2}-4 c_{2} c_{0}}\right) .
\end{aligned}
$$

dan

Terdapat dua kasus, yaitu:

Kasus 1. Jika $\frac{\beta e b}{\mu(\mu+e)(\mu+\gamma)}>1$, maka $c_{0}<0$ dan $c_{1}, c_{2}>0$, sehingga per-samaan (9) mempunyai satu akar real positif dan satu akar real negatif, yaitu berturut-turut $I_{1}$ dan $I_{2}$. Dengan kata lain, terdapat satu titik ekuilibrium endemik.

Kasus 2. Jika $\frac{\beta e b}{\mu(\mu+e)(\mu+\gamma)}<1$, maka $c_{0}, c_{1}, c_{2}>0$, sehingga persamaan (9) mempunyai dua akar negatif. Dengan kata lain, tidak ada titik ekuilibrium endemik.

Berdasarkan kedua kasus di atas dan $I$ bermakna secara biologi untuk, maka diambil

$$
I=\frac{1}{2 c_{2}}\left(-c_{1}+\sqrt{c_{1}^{2}-4 c_{2} c_{0}}\right) \text {. }
$$

Jika nilai $I$ disubstitusikan pada persamaan (7) diperoleh :

$$
E=\frac{(\gamma+\mu)}{e}\left(\frac{1}{2 c_{2}}\left(-c_{1}+\sqrt{c_{1}^{2}-4 c_{2} c_{0}}\right)\right) \text {. }
$$

Dari persamaan (11) dan (12), diperoleh : 


$$
\begin{aligned}
& E>0 \Leftrightarrow I>0 \text { dan } \\
& I>0 \Leftrightarrow \frac{\beta e b}{\mu(\mu+e)(\mu+\gamma)}>1
\end{aligned}
$$

Selanjutnya, dimisalkan

$$
R_{0}=\frac{\beta e b}{\mu(\mu+e)(\mu+\gamma)} \text {. }
$$

Jadi, titik ekuilibrium endemik Sistem (6) adalah :

$T_{*}=\left(S_{*}, E_{*}, I_{*}\right)=\left(\frac{(\mu+e)(\mu+\gamma)}{\beta e}\left(1+\alpha I_{*}{ }^{2}\right), \frac{(\gamma+\mu)}{e} I_{*}, I_{*}\right)$

dengan $I_{*}$ adalah akar positif dari persamaan kuadrat

$$
q\left(I_{*}\right):=\frac{\alpha b}{R_{0}} I_{*}^{2}+\frac{\beta b}{\mu R_{0}} I_{*}+\frac{b}{R_{0}}\left(1-R_{0}\right)=0
$$

Teorema 1. Diberikan $\bar{T}, T_{*}$, dan $R_{0}$ berturut-turut diberikan oleh (9), (14), dan (13).

(i) Jika $R_{0}<1$, maka Sistem (3) mempunyai satu titik ekuilibrium $\bar{T}$.

(ii) Jika $R_{0}>1$, maka Sistem mempunyai dua titik ekuilibrium, yaitu $\bar{T}$ dan $T_{*}$.

\section{Kestabilan Titik Ekuilibrium}

Pada bagian ini dianalisis kestabilan lokal masing-masing titik ekuilibrium dari Sistem (3).

Theorema 2. Diberikan nilai awal $\left(S_{0}, E_{0}, I_{0}\right) \in R_{+}^{3}, \quad \operatorname{serta} \bar{T}, T_{*}, \quad$ dan $R_{0}$ berturut-turut diberikan oleh (9), (13), dan (14).

(i) Jika $R_{0}<1$, maka titik ekuilibrium $\bar{T}$ stabil asimtotik lokal.

(ii) Jika $R_{0}>1$, maka titik ekuilibrium $T_{*}$ stabil asimtotik lokal.

\section{Bukti}

(i) Diketahui

$$
R_{0}=\frac{\beta e b}{\mu(\mu+e)(\mu+\gamma)}<1
$$

$$
\begin{aligned}
& \Leftrightarrow \frac{\beta e b}{\mu}<(\mu+e)(\mu+\gamma) \Leftrightarrow \\
& \frac{\beta e b}{\mu}-(\mu+e)(\mu+\gamma)<0
\end{aligned}
$$

Kestabilan lokal titik ekuilibrium $\bar{T}$ diselidiki dengan mengevaluasi linearisasi dari Sistem (3) di titik tersebut. Sebelumnya ditentukan matriks Jacobian

$J=\left[\begin{array}{lll}\frac{\partial f_{1}}{\partial Z} & \frac{\partial f_{1}}{\partial I} & \frac{\partial f_{1}}{\partial V} \\ \frac{\partial f_{2}}{\partial Z} & \frac{\partial f_{2}}{\partial I} & \frac{\partial f_{2}}{\partial V} \\ \frac{\partial f_{3}}{\partial Z} & \frac{\partial f_{3}}{\partial I} & \frac{\partial f_{3}}{\partial V}\end{array}\right]$.

Ruas kanan Sistem (3) berturutturutmerupakan $f_{1}, f_{2}$, dan $f_{3}$, sehingga

$$
J=\left[\begin{array}{ccc}
-\left(\frac{\beta I}{1+\alpha I^{2}}+\mu\right) & 0 & -\frac{\beta S\left(1-\alpha I^{2}\right)}{\left(1+\alpha I^{2}\right)^{2}} \\
\frac{\beta I}{1+\alpha I^{2}} & -(\mu+e) & \frac{\beta S\left(1-\alpha I^{2}\right)}{\left(1+\alpha I^{2}\right)^{2}} \\
0 & e & -(\mu+\gamma)
\end{array}\right] .
$$

Jika titik ekuilibrium $\bar{T}=(\bar{S}, \bar{E}, \bar{I})=\left(\frac{b}{\mu}, 0,0\right)$ dievaluasikan pada matriks $J$ pada persamaan (6) diperoleh :

$$
J(\bar{T})=\left[\begin{array}{ccc}
-\mu & 0 & -\frac{\beta b}{\mu} \\
0 & -(\mu+e) & \frac{\beta b}{\mu} \\
0 & e & -(\mu+\gamma)
\end{array}\right] .
$$

Dari matriks $J(\bar{T})$ diperoleh persamaan karakteristik sebagai berikut :

$\operatorname{det}(\lambda I-J(\bar{T}))=$

$(\lambda+\mu)\left(\lambda^{2}+(\gamma+e+2 \mu) \lambda+(\mu+e)(\mu+\gamma)-\frac{\beta e b}{\mu}\right)=0$

Persamaan (18) dipenuhi untuk $\lambda=-\mu$ atau

$\lambda^{2}+(\gamma+e+2 \mu) \lambda+(\mu+e)(\mu+\gamma)-\frac{\beta e b}{\mu}=0$

sehingga diperoleh satu nilai eigen negatif. Dengan demikian, tinggal menentukan nilai eigen dari persamaan (19) yang merupakan persamaan karakteristik dari matriks :

$J_{1}=\left[\begin{array}{cc}-(\mu+e) & \frac{\beta b}{\mu} \\ e & -(\mu+\gamma)\end{array}\right]$. 
Dari matriks tersebut diperoleh:

$$
\begin{aligned}
\operatorname{tr}\left(J_{1}\right) & = \\
& -(\mu+e)-(\mu+\gamma) \\
& =-2 \mu-(e+\gamma)<0
\end{aligned}
$$

dan

$$
\operatorname{det}\left(J_{1}\right)=(\mu+e)(\mu+\gamma)-\frac{\beta e b}{\mu}>0 .
$$

Akibatnya semua nilai eigen matriks $J_{1}$ mempunyai bagian real negatif. Jadi, titik ekuilibrium $\bar{T}$ stabil asimtotik lokal.

(ii) Kestabilan lokal titik ekuilibrium $T_{*}$ diselidiki berdasarkan teori umum center manifold. Untuk menjelaskan hal ini, diberikan sistem umum persamaan diferensial dengan parameter $\phi$ :

$$
\frac{d x}{d t}=f(x, \phi), f: R^{n} \times R \rightarrow R^{n},(20)
$$

dengan $f \in C^{2}\left(R^{n} \times R\right)$. Tanpa mengurangi keumuman, diasumsikan bahwa 0 adalah titik ekuilibrium Sistem (20) untuk semua nilai parameter $\phi$, yaitu

$$
f(0, \phi) \equiv 0, \quad \text { untuk setiap } \quad \phi
$$

Teorema 3.Diberikan $J=D_{x} f(0,0)=\left(\frac{\partial f_{i}}{\partial x_{j}}\right)$ adalah matriks linearisasi Sistem (2.50) di sekitar titik ekuilibrium 0 dengan $\phi$ dievaluasikan di 0.

(i) Nol adalah nilai eigen sederhana dari matriks $J$ dan semua nilai eigen lain dari matriks $J$ mempunyai bagian real negatif.

(ii) Matriks J mempunyai sebuah vektor eigen kanan nonnegatif $w$ dan sebuah vektor eigen kiri $v$ yang bersesuaian dengan nilai eigen nol.

Diambil $f_{k}$ adalah komponen ke- $k$ dari $f$ dan

$$
\begin{aligned}
& a=\sum_{k, i, j=1}^{n} v_{k} w_{i} w_{j} \frac{\partial^{2} f_{k}}{\partial x_{i} \partial x_{j}}(0,0), \\
& (22) c=\sum_{k, i=1}^{n} v_{k} w_{i} \frac{\partial^{2} f_{k}}{\partial x_{i} \partial \phi}(0,0) .
\end{aligned}
$$

Dinamik lokal dari Sistem (20) di sekitar titik 0 sepenuhnya ditentukan oleh nilai $a$ dan $c$.

$a, c>0$. Jika $\phi<0$ dengan $|\phi|<<1$, maka 0 stabil asimtotik lokal, dan terdapat sebuah titik ekuilibrium positif tidak stabil; Jika $0<\phi<<1,0$ tidak stabil dan terdapat sebuah titik ekuilibrium negatif stabil asimtotik lokal.

$a, c<0$. Jika $\phi<0$ dengan $|\phi|<<1$, maka 0 tidak stabil; Jika $0<\phi<<1$, 0 stabil asimtotik lokal dan terdapat sebuah titik ekuilibrium positif tidak stabil.

$a>0$ dan $c<0$. Jika $\phi<0$ dengan $|\phi|<<1$, maka 0 tidak stabil dan terdapat sebuah titik ekuilibrium negatif stabil asimtotik lokal; Jika $0<\phi<<1, \quad 0$ stabil dan terdapat suatu titik ekuilibrium positif tidak stabil.

$a<0$ dan $c>0$. Jika $\phi$ berubah dari negatif menjadi positif, maka kestabilan 0 berubah dari stabil menjadi tidak stabil, dan titik ekuilibrium negatif tidak stabil menjadi titik ekuilibrium positif stabil asimtotik lokal.

Sekarang diambil $\phi=\beta$ sebagai parameter bifurkasi, sedemikian sehingga $R_{s}<1$ untuk $\phi<0$ dan $R_{s}>1$ untuk $\phi>0$, sedemikian sehingga $x_{0}$ adalah titik ekuilibrium bebas penyakit untuk semua nilai $\phi$. Diberikan sistem:

$\dot{x}=f(x, \phi)$,

dengan $f$ diferensiabel kontinu paling sedikit dua kali terhadap $x$ dan $\phi$. Titik ekuilibrium bebas penyakit adalah garis $\left(x_{0}, \phi\right)$ dan kestabilan lokal titik ekuilibrium bebas penyakit berubah di titik $\left(x_{0}, \phi\right)$. Sekarang akan ditunjukkan bahwa terdapat 
titik ekuilibrium nontrivial di dekat titik bifurkasi $\left(x_{0}, 0\right)$.

Dengan transformasi $S=x_{1}, E=x_{2}$, $I=x_{3}$, dan $R=x_{4}$, Sistem (2) menjadi :

$\frac{d x_{1}}{d t}=b-\frac{\phi x_{1} x_{3}}{1+\alpha x_{3}^{2}}-\mu x_{1}:=f_{1}$,

$\frac{d x_{2}}{d t}=\frac{\phi x_{1} x_{3}}{1+\alpha x_{3}^{2}}-(\mu+e) x_{2}:=f_{2}$,

$\frac{d x_{3}}{d t}=e x_{2}-(\gamma+\mu) x_{3}:=f_{3}$,

$\frac{d x_{4}}{d t}=\gamma x_{3}-\mu x_{4}:=f_{4}$.

Dengan mengambil $R_{s}=1$, diperoleh

$$
\begin{aligned}
& R_{s}=\frac{\phi e b}{\mu(\mu+e)(\mu+\gamma)} \Leftrightarrow \\
& 1=\frac{\phi e b}{\mu(\mu+e)(\mu+\gamma)} \\
& \Leftrightarrow \phi=\frac{\mu(\mu+e)(\mu+\gamma)}{e b}
\end{aligned}
$$

$\phi$ adalah parameter bifurkasi.

Dengan mensubstitusi $\phi$ dalam $J(\bar{T})$ diperoleh

$$
J(\phi)=\left[\begin{array}{ccc}
-\mu & 0 & -\frac{(\mu+e)(\mu+\gamma)}{e} \\
0 & -(\mu+e) & \frac{(\mu+e)(\mu+\gamma)}{e} \\
0 & e & -(\mu+\gamma)
\end{array}\right] .
$$

Nol adalah nilai eigen sederhana dari matriks $J(\phi)$, sehingga dapat digunakan teori center manifold.

Vektor eigen kiri $v=\left(v_{1}, v_{2}, v_{3}\right)$ dicari dari persamaan matriks

$$
\left(v_{1}, v_{2}, v_{3}\right)\left[\begin{array}{ccc}
-\mu & 0 & -\frac{(\mu+e)(\mu+\gamma)}{e} \\
0 & -(\mu+e) & \frac{(\mu+e)(\mu+\gamma)}{e} \\
0 & e & -(\mu+\gamma)
\end{array}\right]=0
$$

Sehinggadiperoleh $-\mu v_{1}=0$,

$$
\begin{aligned}
& -(\mu+e) v_{2}+e v_{3}=0, \\
& -\frac{(\mu+e)(\mu+\gamma)}{e} v_{1}+\frac{(\mu+e)(\mu+\gamma)}{e} v_{2}-(\mu+\gamma) v_{3}=0
\end{aligned}
$$

Sistem persamaan (26) dipenuhi untuk :

$$
v_{1}=0 \text { dan } v_{3}=\left(\frac{\mu+e}{e}\right) v_{2}
$$

dengan $v_{2}$ dapat diambil nilai sebarang. Untuk $v_{2}=1$, maka vektor eigen kiri adalah $v=(0, e, \mu+e)$.

Selanjutnya, vektor eigen kanan $w=\left(w_{1}, w_{2}, w_{3}\right)$ dicari dari persamaan

$$
\left[\begin{array}{ccc}
-\mu & 0 & -\frac{(\mu+e)(\mu+\gamma)}{e} \\
0 & -(\mu+e) & \frac{(\mu+e)(\mu+\gamma)}{e} \\
0 & e & -(\mu+\gamma)
\end{array}\right]\left(\begin{array}{l}
w_{1} \\
w_{2} \\
w_{3}
\end{array}\right)=0
$$

sehingga diperoleh

$-(\mu+e) w_{2}+\frac{(\mu+e)(\mu+\gamma)}{e} w_{3}=0$

$e w_{2}-(\mu+\gamma) w_{3}=0$.

Sistem persamaan (27) dipenuhi untuk:

$w_{1}=-\frac{(\mu+e)(\mu+\gamma)}{\mu e}, \quad w_{2}=\frac{\mu+\gamma}{e}, \quad$ dan $w_{3}=1$.

Oleh karena itu, vektor eigen kanan adalah : $\left(\begin{array}{c}-(\mu+e)(\mu+\gamma) \\ \mu(\mu+\gamma) \\ \mu e\end{array}\right)$.

Dengan mengevaluasi turunan parsial di titik ekuilibrium bebas penyakit, diperoleh

$$
\frac{\partial f_{2}}{\partial x_{1} \partial x_{3}}=\phi, \quad \frac{\partial f_{2}}{\partial x_{3} \partial x_{1}}=\phi,
$$$$
\frac{\partial f_{2}}{\partial x_{1} \partial \phi}=0, \frac{\partial f_{2}}{\partial x_{3} \partial \phi}=\frac{b}{\mu} \text {. }
$$

Sekarang dicari nilai $a$ dan $c$, yaitu

$$
\begin{aligned}
& a=\frac{1}{2}\left(v_{2} w_{1} w_{3} \phi+v_{2} w_{3} w_{1} \phi\right) \\
& =-\frac{(\mu+e)(\mu+\gamma)}{\mu e}<0 \text { dan } \\
& c=v_{2} w_{1} 0+v_{2} w_{3}\left(\frac{b}{\mu}\right)=\frac{b}{\mu}>0
\end{aligned}
$$

Karena $a<0$ dan $c>0$, maka terdapat bifurkasi yang mengakibatkan jika $R_{0}>1$ maka titik ekuilibrium endemik stabil asimtotik lokal, tapi hanya untuk $R_{0}$ cukup dekat dengan 1. 


\section{SIMPULAN}

Adapun kesimpulan dari penelitian ini adalah :

1. Model epidemi SEIR merupakan model penyebaran penyakit yang terjadi pada kelompok-kelompok individu yang berbeda, yaitu kelas susceptible (kelas individu yang rentan penyakit), kelas exposed (kelas individu yang telah terinfeksi namun belum sakit atau masa laten), kelas infected (kelas individu yang telah terjangkit penyakit) dan kelas recovered (kelas individu yang telah sembuh).

2. Model matematika epidemi SEIR dengan laju insidensi jenuh yang memiliki kemampuan infeksi pada periode laten, infeksi dan sembuh adalah

$$
\begin{aligned}
& \frac{d S}{d t}=b-\frac{\beta S I}{1+\alpha I^{2}}-\mu S ; t \geq 0, \\
& \frac{d E}{d t}=\frac{\beta S I}{1+\alpha I^{2}}-(\mu+e) E ; \quad t \geq 0, \\
& \frac{d I}{d t}=e E-(\gamma+\mu) I ; t \geq 0, \\
& \frac{d R}{d t}=\gamma I-\mu R ; t \geq 0, \\
& S(0)=S_{0}, E(0)=E_{0}, I(0)=I_{0},
\end{aligned}
$$

3. Kestabilan titik-titik ekuilibrium model epidemi SEIR diatas adalah stabil asimtotik lokal dengan menyelidiki linearisasi dari sistem persamaan diferensial model epidemi SEIR. Selanjutnya titik-titik ekuilibrium tersebut diselidiki dengan menggunakan metode Lyapunov dan diperoleh bahwa titik ekuilibriumnya stabil asimtotik lokal.

\section{SARAN}

Karena berbagai keterbatasan, penulis menyadari penelitian dan tulisan ini masih banyak kekurangannya. Banyak hal yang belum tercakup dalam penelitan ini. Perlu dikaji lebih lanjut generalisasi untuk kestabilan model epidemi lainnya dan simulasi numeriknya.

\section{DAFTAR PUSTAKA}

Anton H, dan Rorres,C.,2004. Aljabar Linear Elementer Versi Aplikasi, Edisi Kedelapan, alih bahasa oleh Indriasari, R dan Harmaen,I., Erlangga, Jakarta.

Arrowsmith, D.R. dan Place, C.M., 1992, Dynamical System Differential Equation, Maps and Chaotic Behaviour, Chapman \& Hall Mathematic, London.

Bazaraa, M.S., Sheraly, H.D, and Shetty, C.M., Nonlinear Programming Theory and Algorithms, John Wiley \& Sons, Inc, New York, 1993.

Becerra, M.V., 2008. La Salle's Invariant Set Theory, http://www.personal.rdg.ac.uk/ shs99 $\mathrm{vmb} /$ notes/anc/lecture3.pdf

Boyd, Stephen, 2008, Basic Lyapunov Theory, Stanford University, http://www.stanford.edu/class/ee363/1 yap.pdf

Capazzo, V., Mathematical Structures of Epidemic Systems, Springer-Verlag, Heidelberg, 2008.

Chong, K.P and Stainslow, H.Z., An Introduction to Optimization, John Wiley \& Sons, University of New Hampshire, 1984.

Debarre, F., SIR Models of Epidemics, Theoretical Biology.

Gantmacher, F.R., 1959, The Theory of Matrices, Chelsea Publishing Company, New York.

Hanh, Wolfgang, 1967, Stability of Motion, Springer - Verlag, New York.

Hirsch, M.W., dan Smith, Monotone Dynamical Systems, University of California, Berkeley, 2004.

Iwami. S, Takeuchi, Y., dan Liu, X., 2007. Avian - human Influenza Epidemic Model, Mathematical Biosciences 2007, hal 1-25. 
Feng J., dan Hadeler,K.P., Qualitative Behaviour of Some Simple Networks, Mathematical Gen. 1996, hal 50195033.

Kocak, H. dan Hole, J.K., 1991, Dynamic and Bifurcation, Springer - Verlag, New York.

Leon, J.S., Aljabar Linear dan Aplikasinya, Edisi Kelima, Alih bahasa olehBondan,A. Erlangga, Jakarta, 1998.

Luenberger, G.D., 1979, Introduction to Dynamic System Theory, Models \& Aplication, John Wiley \& Sons, New York.

Ngwenga, O., The Role of IncidenceFunctions on the Dynamics of SEIR Model, African Institute for Mathematical Science (AIMS), 2009.

Olsder, G.J., 1994, Mathematical System Theory, Delftse Uitgevers Maatschappij, Netherlands.

Perko L., 1991, Differential Equations and Dynamical Systems, Springer Verlag, New York.

Ross, S.L., Differential Equations, edition, John Wiley \& Sons, University of New Hampshire, 1984.

Verhultz, Ferdinand, 1990, Nonlinear Differential Equations and Dynamical Systems, Springer Verlag, Berlin.

Wiggins S, 1990, Introduction to Applied Nonlinear Dynamical Systems and Chaos, Springer - Verlag, New York 